\title{
A high-resolution Late-Glacial - Holocene pollen diagram from Pian di Gembro (Central Alps, Northern Italy)
}

\author{
Roberta Pini \\ C.N.R. - Istituto per la Dinamica dei Processi Ambientali, Piazza Cittadella 4, 24129 Bergamo (I) and Institut of Plant Sciences, \\ Altenbergrain 21, University of Bern (CH), e-mail: cnrbg@uninetcom.it
}

Received February 4, 2002 / Accepted August 2, 2002

\begin{abstract}
The local and regional history of vegetation and climate, from the Late Glacial to the present, is represented in a new, high-resolution pollen diagram from Pian di Gembro ( $1350 \mathrm{~m}$ asl), ten ${ }^{14} \mathrm{C}$ dates providing a reliable time control. An open pioneer vegetation dominated by Artemisia, Gramineae, and Chenopodiaceae followed the retreat of the glaciers after the Last Glacial Maximum. Shrub vegetation with Juniperus, Alnus viridis, and Salix expanded soon after. Denser Betula-Pinus forests were present in Pian di Gembro around 12,320 B.P. Their extent was greatly reduced by the climatic cooling of the Younger Dryas, when open vegetation spread again. The beginning of the Holocene was marked by a considerable expansion in mixed oak taxa. Corylus immigrated to the site at 9,250 B.P. Picea and Abies expanded at 7,370 B.P., recording an abrupt change in the structure of the vegetational belts. A coeval climatic change is evidenced in the GRIP records and also detectable through oscillations of the timberline. Signs of human impact are present since late Atlantic, becoming more intense around 2,200 B.P. As pasture lands increased, Abies and Fagus slowly disappeared. The introduction of Castanea and Juglans is dated to Roman times, and Secale to the Middle Ages.
\end{abstract}

Keywords: N Italy - Late Glacial/Holocene - Immigration $-8,200$ cal B.P. event - Human impact

\section{Introduction}

Several alpine and pre-alpine glaciers formed numerous lakes and mires in the Italian Central Alps at different altitudes. In the last 20 years various efforts have been made to reconstruct past vegetation and climate by means of multidisciplinary investigations of these lacustrine and peaty sediments (Burga 1987; Wick 1994; Fedele and Wick 1996). Nevertheless the Late Glacial and Holocene history of this area is so complex that only high-resolution analysis can reveal climatic oscillations in an alpine environment. Recent investigations have shown that during the Holocene several climatic phases occurred in the Alps (Orombelli and Pelfini 1985; Orombelli 1996; Orombelli and Mason 1997). Zoller et al. (1966) and Zoller (1967) described climatic and glacial oscillations (named Misox, Piora, Göschenen) in the Gotthard region. Correlations with glacial advances in Austria and North America were also discussed. Patzelt and Bortenschlager (1973) brought further confirmation and improvement to the knowledge of these oscillations. Other climatic phases (Venediger, Frosnitz, Rotmoos, Löbben) were indicated for the Eastern Alps. In the last decades new investigations were made which confirmed the existence and the amplitude of the oscillations previously proposed (Wick and Tinner 1997). Detailed palaeobotanical analysis is thus required to investigate the reactions of vegetation to cold and warm periods.

The aim of this paper is to present a new high-resolution pollen diagram from Pian di Gembro ( $1350 \mathrm{~m}$ asl, Val Camonica, Central Alps), a key site for understanding the past vegetation and climate in Central Northern Italy. The high resolution of this palynological investigation, together with reliable ${ }^{14} \mathrm{C}$ dates, can be used for tracing the history of an area which, for biogeographic reasons, represents a junction point of early tree migration. Furthermore, the climate of this part of the Alps is influenced by the Insubric regime, the sub-Mediterranean regime (typical of the region of Lago di Garda) and the continentality of the valley floor of inner Valtellina. Val Camonica is an important study area where several factors could have influenced the history of the vegetation.

Because of the large data set available, this paper is only a descriptive overview of the local and regional history of vegetation and climate. Specific topics will be discussed in future papers.

A palaeobotanical investigation of 5 localities in $\mathrm{Val}$ Camonica was carried out by Gehrig (1997), pollen percentage and influx diagrams, together with several ${ }^{14} \mathrm{C}$ dates providing a detailed picture of the vegetation and climate during the Late Glacial and Holocene.

A previous palynological study of the site investigated here was made by Zoller et al. (University of Basel) between 1973 and 1975, and two detailed pollen profiles provided with ${ }^{14} \mathrm{C}$ dates were presented at the ALPQUA meeting in 1977. Because of the discrepancies between pollen stratigraphy and ${ }^{14} \mathrm{C}$ chronology during the Late Glacial and early Holocene, these were never published in 
a regular journal. The date for the deepest organic material from the cores $(13,490$ cal B.P.: Zoller et al. 1977) indicates that the Pian di Gembro succession extends from the early Late Glacial through the entire Holocene. It is therefore a useful site for the reconstruction of vegetation history and climate during this time interval. A collaboration between the Universities of Milano and Bern made it possible to again undertake the study of the stratigraphical sequence of Pian di Gembro.

\section{The study area (geographical and geological setting, climate)}

The Pian di Gembro peat mire (1350 $\mathrm{m}$ asl) is located in the Italian Central Alps (province of Sondrio, Lombardy), a few $\mathrm{km}$ north of the Aprica Pass (Fig. 1a,b). It is one of the largest peat mires in Italy: its longest axis is $2.5 \mathrm{~km}$ long, while the shortest one is $250-300 \mathrm{~m}$ long (Figs. 2, 3, 4). The mire is located in a saddle deeply cut into the bedrock (metamorphic rocks of the Scisti di Edolo Formation) at the watershed of Val Camonica and Valtellina. This depression is filled by glacial, lacustrine, and peaty sediments. Two coalescent debris cones (Fig. 2) divide the peat mire in two sectors. Accumulation of peat has occurred mainly in the western sector, the drainage of which is controlled by the activity of the debris cones. The smaller eastern sector has a small outlet draining towards Valtellina.

The origin of the complex morphology of this area is not yet clear, but it is unlikely that the erosion of the Adda glacier during the Last Glacial Maximum was itself responsible for the excavation of the depression of Pian di Gembro, which already existed. This is revealed by the great depth down to the bedrock in the $\mathrm{W}$ part of the mire (more than $35 \mathrm{~m}$ : Dal Piaz 1929). Tectonic activity linked to the presence of the Insubric fault probably played an important role in the genesis of the depression of Pian di Gembro.

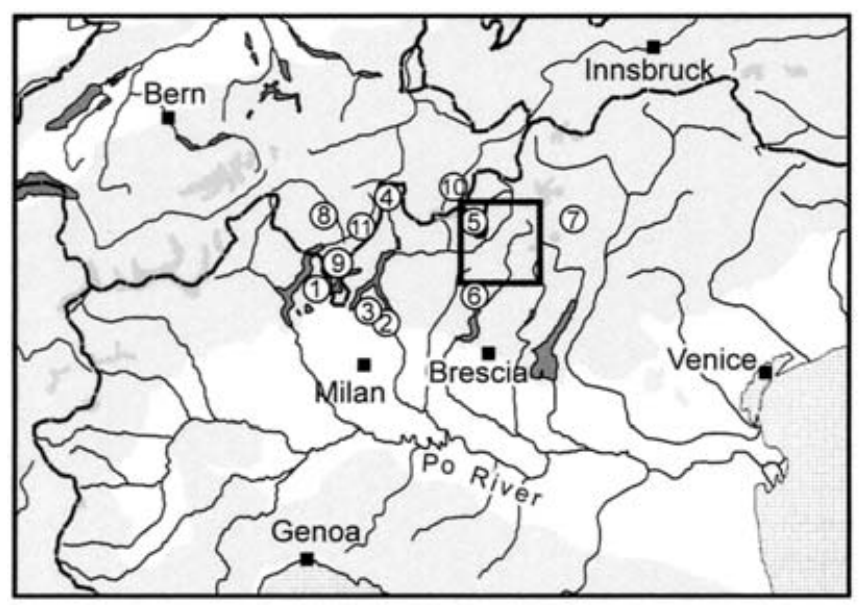

Fig. 1. Map A shows Northern Italy, neighbouring countries, and sites mentioned in the text:

1 - Lago di Ganna (Schneider and Tobolski 1985); 2 - Lago di Annone (Wick 1996); 3 - Lago del Segrino (Wick 1996); 4 Pian dei Cavalli (Wick 1994); 5 - Selva (Burga 1987); 6 - Cerete (Orombelli and Ravazzi 1995); 7 - Val di Sole (Speranza et al 1996) - Chanoua (Zoller et al. 1996); 11 - Pian di Signano (Zoller 1960)

Map B illustrates the study region and locations of sites mentioned in the text: 1 - Pian di Gembro (this paper); 2 - Palù di Edolo ; 3 - Col di Val Bighera; 4 - Passo del Tonale (2 - 4, Gehrig 1997)
It has been well known since the 1970s that the Pian di Gembro mire contains one of the more complete stratigraphical successions found in the Italian Central Alps. As revealed by radiocarbon dating it is a natural archive covering at least the last 15,000 years (ETH, Zurich, Zoller et al. 1977).

Climate strongly shows the effects of continentality, typical of the valley floor of inner Valtellina. Nevertheless, many local factors (mainly the high daily evapotranspiration and the related humidity) modify the macro- and meso-climate, making these peculiar and difficult to resolve into rigorous patterns.

\section{Present-day vegetation and alterations to the peat mire}

A composite mosaic of vegetation characterises the peat mire, showing features that are commonly present in intermediate bogs (Phragmitetea, Utricularietea, Scheuchzerio-Caricetea fuscae, Oxycocco-Sphagnetea, Rhynchosporetum albae: Andreis and Rodondi, 1982). Mostly during the last century, up to the end of the Second World War, the peat mire of Pian di Gembro suffered from severe environmental alterations caused by intense anthropic pressure. Sphagnum and Ericaceae were harvested largely as litter for cowsheds. An area of about 2.5 ha in the western part of the peat mire has been severely damaged by Sphagnum and peat exploitation leaving pools $2.5 \mathrm{~m}$ deep as traces of past activities. Re-colonizing vegetation communities began to grow after the end of these activities (Andreis et al. 1999). In 1983 Pian di Gembro became a Natural Reserve of Lombardy.

\section{Regional vegetation}

Nowadays the slopes surrounding the peat mire are covered by forests dominated by Picea abies, Larix decidua, and Pinus sylvestris (Fig. 5). Betula alba, Populus

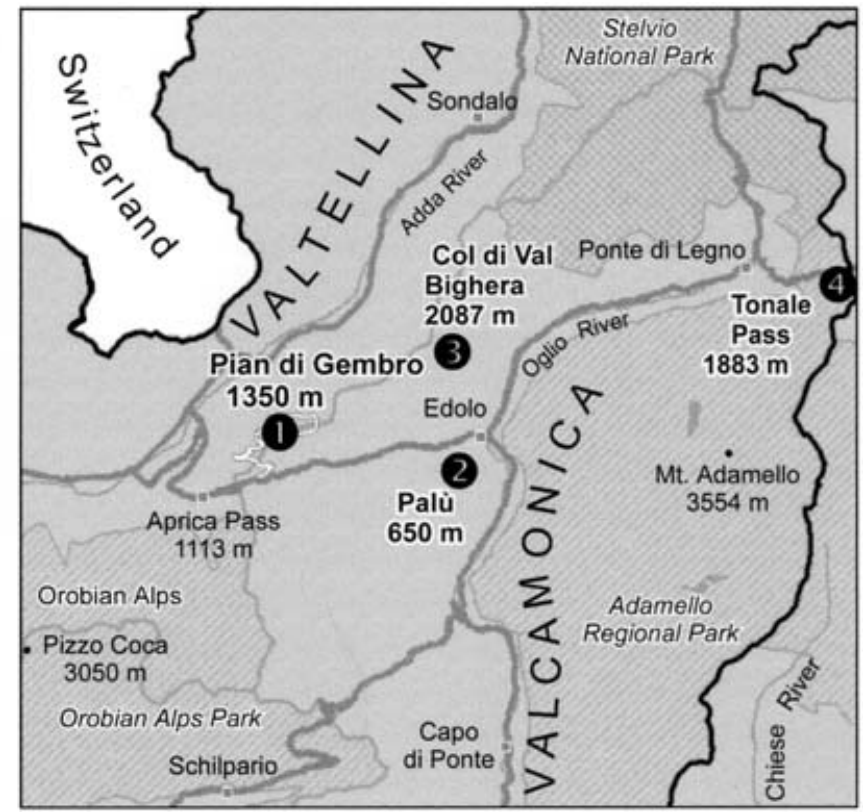




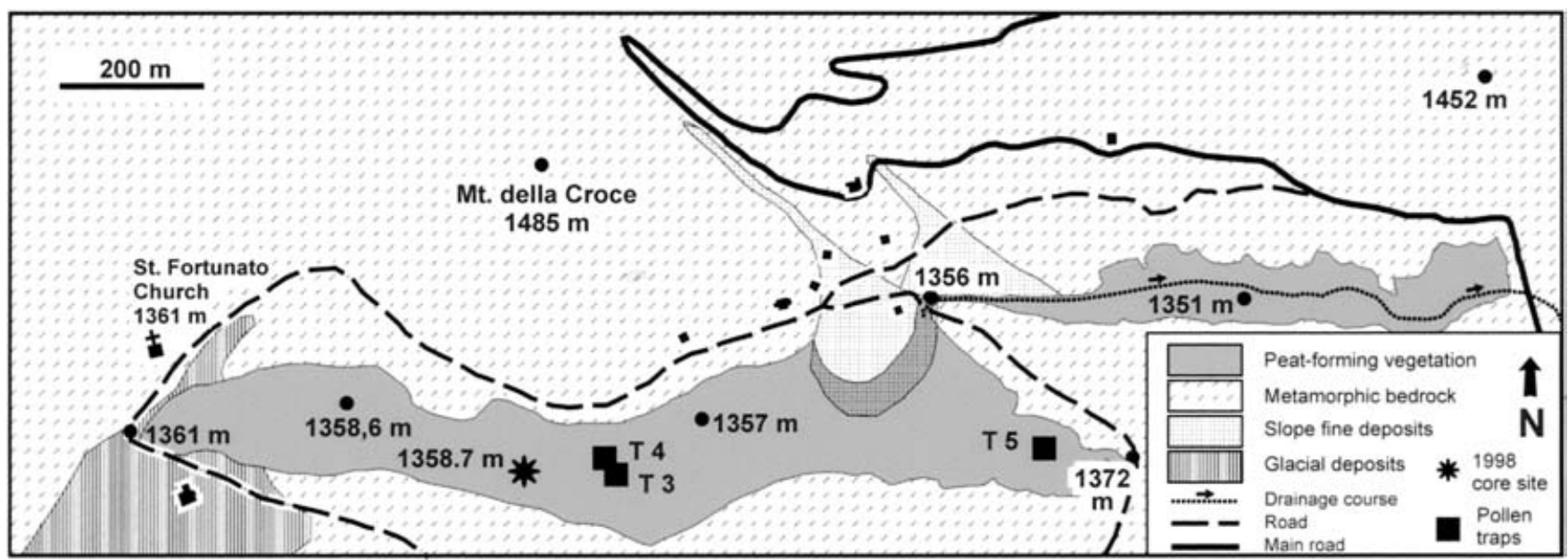

Fig. 2. Geological and geomorphological sketch of the peat mire of Pian di Gembro. The 1998 coring site is indicated by an asterisk. Positions of pollen traps are indicated by black squares

tremula, Juniperus communis, and Vaccinium spp. are present, the latter often dominating the understorey. Quercus petraea and Corylus avellana occur sporadically.

The main features of the vegetation of the nearby valleys (Val Camonica and Valtellina) are described here, based on existing literature (Valtellina: Credaro and Pirola 1975) and on original observations (Val Camonica: Ravazzi and Pini, June 2002, see Fig. 5). Later in this paper the modern vegetation will be compared with new data on modern pollen rain from pollen traps placed in Pian di Gembro. This comparison may help to interpret the vegetational history of the study area.

The vegetation of the valley floor of Val Camonica is dominated by Fraxinus excelsior and sporadic Alnus incana. On south-facing slopes below $1000 \mathrm{~m}$ asl, Quercus petraea is abundant, together with Fraxinus excelsior, Corylus avellana, Populus tremula, Larix decidua and Prunus avium. Conifer forests, dominated by Larix decidua and Picea abies, are present on north-facing slopes. Moving towards higher altitudes, Fraxinus excelsior decreases, being limited to moister sites together with Salix capraea, Alnus incana, Sambucus nigra and sporadic Acer pseudoplatanus, Sorbus aucuparia and Tilia spp. Quercus petraea is the dominant tree up to 1300 $\mathrm{m}$ asl, accompanied by Betula alba, Populus tremula,

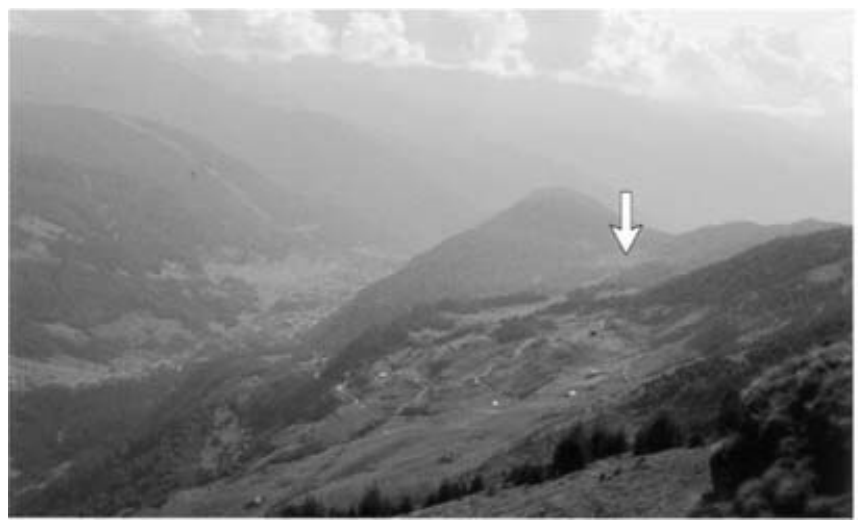

Fig. 3. View of the peat mire of Pian di Gembro as seen from Mt. Padrio
Corylus avellana, Pinus sylvestris, Frangula alnus and Rhamnus saxatilis. Pteridium aquilinum is very abundant. At about $1300 \mathrm{~m}$ asl mixed forests dominated by conifers (mostly Larix decidua and Picea abies) take the place of the Quercus forests. At higher altitudes, between 1600$1900 \mathrm{~m}$ asl, large areas are alpine pasture land. Larix parklands occur on low-energy slopes, with sporadic Picea abies and Pinus sylvestris. Alnus viridis dominates the vegetation above $1900 \mathrm{~m}$ asl.

Credaro and Pirola (1975) have described the vegetation of Valtellina. The natural vegetation of the submontane belt has been largely modified by anthropic pressure. Forests of Fraxinus ornus and Ostrya carpinifolia, showing affinities with some Mediterranean mixed-oak forests, can be regarded as traces of the 'climax vegetation'. The lower montane belt is made up of mixed-oak forests with Fagus sylvatica, Fraxinus excelsior, Tilia cordata, Quercus petraea, Quercus pubescens, etc. Picea abies is widely distributed in the upper montane belt and in the lower subalpine belt, Pinus cembra and Larix decidua being present in the latter. Pinus cembra, Pinus mugo, and Larix decidua characterise the upper subalpine belt. Finally, the alpine belt is dominated by pasture lands and shrubs.

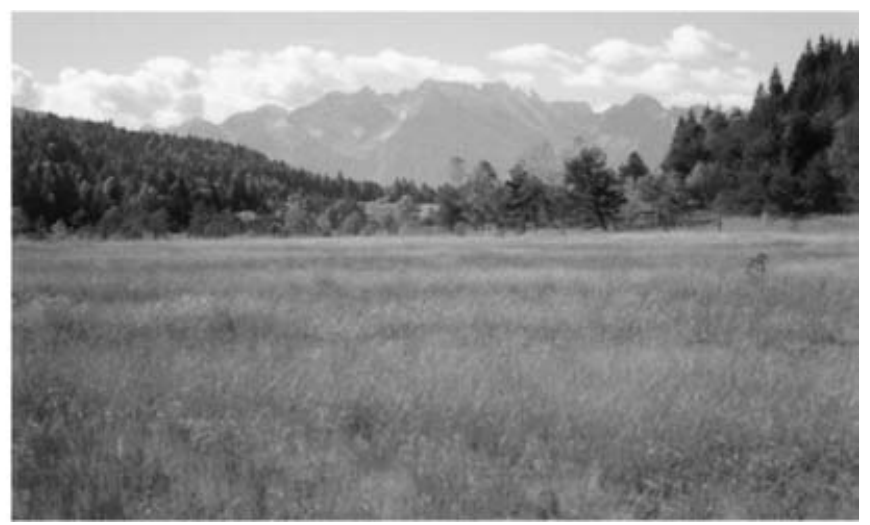

Fig. 4. The peat mire of Pian di Gembro and the Adamello Massif 


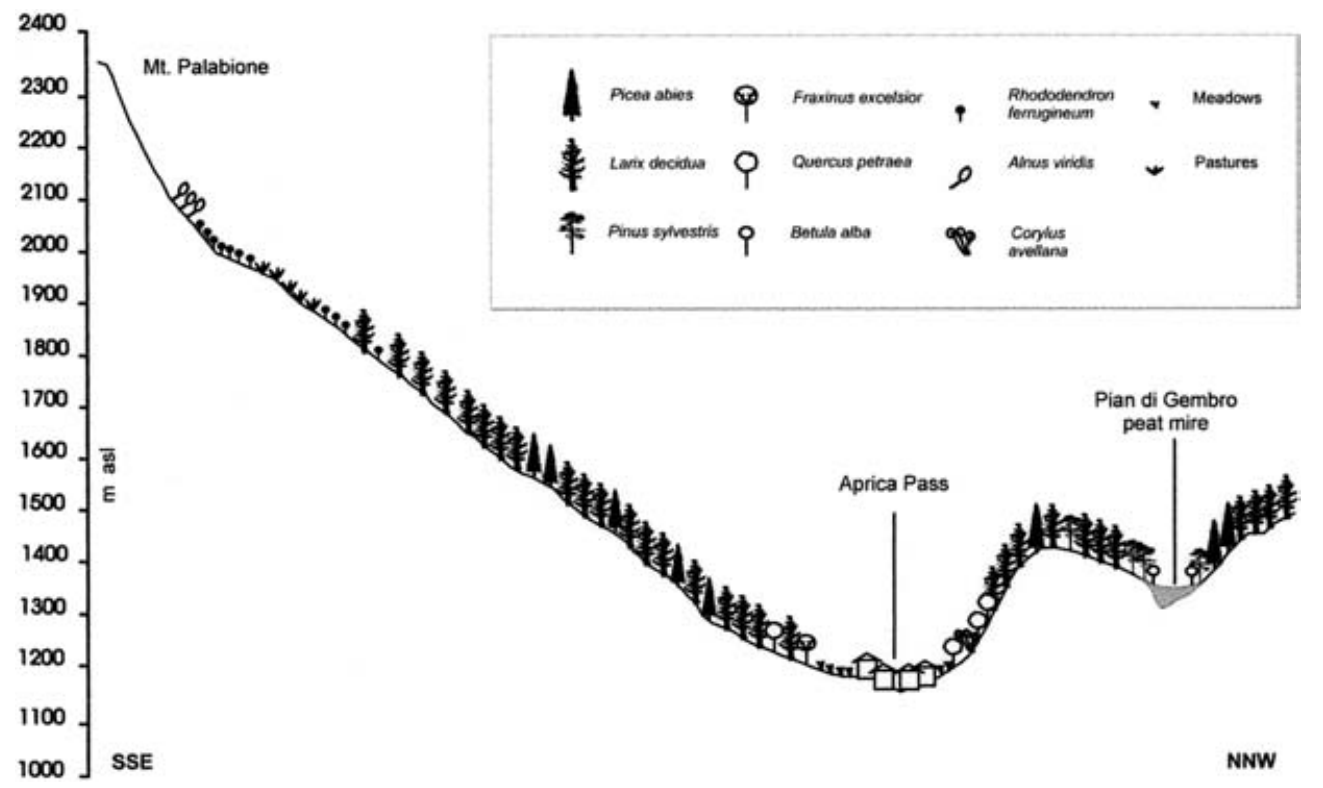

Fig. 5. Scheme of the present-day vegetation along a NNW-SSE transect through Val Camonica. The vertical scale is exaggerated $x 2$

The use of pollen traps to monitor modern pollen rain

Seven pollen traps were placed in different sectors of the peat mire of Pian di Gembro to evaluate modern pollen deposition. Only three of them recorded the pollen rain over two years (1996-1998) and data from selected taxa are summarised here (Table 1; Pini and Mangili 1998; Pini and Mangili, unpubl.). Nevertheless, these data can be used as a tool to understand and interpret the picture of vegetation revealed by the pollen diagram.

Table 1. Pollen pecentage data from selected taxa found in the pollen traps at Pian di Gembro

\begin{tabular}{|c|c|c|c|c|c|c|}
\hline \multirow[b]{2}{*}{ Taxa } & \multicolumn{2}{|c|}{ Trap nr. 3} & \multicolumn{2}{|c|}{ Trap nr. 4} & \multicolumn{2}{|c|}{ Trap nr. 5} \\
\hline & $\begin{array}{c}96-97 \\
\text { p \% }\end{array}$ & $\begin{array}{c}97-98 \\
\text { p \% }\end{array}$ & $\begin{array}{c}96-97 \\
\text { p \% }\end{array}$ & $\begin{array}{c}97-98 \\
\text { p \% }\end{array}$ & $\begin{array}{c}96-97 \\
\text { p \% }\end{array}$ & $\begin{array}{c}97-98 \\
\text { p \% }\end{array}$ \\
\hline P. sylvestris/mugo & 33.3 & 13.3 & 15.2 & 6.3 & 16.3 & 17.0 \\
\hline Picea & 8.6 & 0.5 & 1.6 & 0.4 & 2.1 & 0.3 \\
\hline Larix & 1.6 & 0.5 & 0.2 & 1.1 & 0.3 & 0.1 \\
\hline Acer & - & - & - & 0.1 & - & 0.1 \\
\hline Alnus glutinosa $\mathrm{t}$. & 6.6 & 11.7 & 7.4 & 6.5 & 4.6 & 1.8 \\
\hline Betula & 13.6 & 16.6 & 15.4 & 13 & 7.6 & 2.4 \\
\hline Carpinus betulus & 0.9 & 0.1 & 1.0 & 0.6 & 0.5 & - \\
\hline Castanea & 3.6 & 8.6 & 4.9 & 7.2 & 6.1 & 3.6 \\
\hline Corylus & 1.0 & 4.6 & 0.5 & 4.0 & 0.2 & 0.1 \\
\hline Fagus & 0.3 & 0.1 & 0.1 & 0.1 & 0.3 & - \\
\hline Fraxinus excelsior & 3.6 & 5.6 & 1.1 & 5.3 & 1.2 & 0.3 \\
\hline Hedera & - & 0.1 & - & - & - & - \\
\hline Juglans & 0.9 & 0.3 & 0.3 & 1.0 & 0.1 & - \\
\hline Ostrya & 1.9 & 8.5 & 0.4 & 7.9 & 0.2 & 0.7 \\
\hline Quercus & 2.3 & 1.9 & 2.2 & 1.0 & 1.6 & 0.2 \\
\hline Tilia & 0.3 & 0.1 & - & - & 0.1 & 0.1 \\
\hline Ulmus & 0.3 & 0.1 & 0.3 & 0.1 & 0.3 & 0.1 \\
\hline Vitis & - & 0.1 & - & - & - & - \\
\hline Arboreal pollen & 76.9 & 75.8 & 46.8 & 60.9 & 43.5 & 27.2 \\
\hline Non-arboreal pollen & 23.1 & 24.2 & 53.2 & 39.1 & 56.5 & 72.8 \\
\hline
\end{tabular}

Pollen trap no. 3 was placed in the northern sector of the peat mire, $70 \mathrm{~m}$ inside its border. The surrounding vegetation is dominated by Sphagnum spp., Rhynchospora alba and Lycopodiella inundata. Pollen trap no. 4 was placed in the northern sector of the mire, surrounded on three sides by Phragmites-dominated vegetation. Sphagnum spp., Calluna vulgaris, Andromeda polifolia, Molinia spp. and Carex spp., etc. are present. Pollen trap no. 5 was placed in the SE sector of the mire, where the vegetation is dominated by Trichophorum caespitosum, and Molinia coerulea. Dense forests containing Picea abies, Larix decidua, Pinus sylvestris and Betula alba grow in the vicinity of the site. For the location of the pollen traps see Fig. 2.

The comparison of present-day vegetation and pollen found in the pollen traps reveals that, among the trees growing around the peat mire, Larix and Picea are underrepresented. On the other hand, the pollen rain from Pinus sylvestris, Betula and Alnus glutinosa t. reflects the presence of these taxa in the vegetation quite well. Pollen from mixed oak taxa (especially deciduous Quercus), which are very abundant up to $1300 \mathrm{~m}$ asl, is scarce in the pollen traps. The abundance of these trees in the vegetation is not reflected by their image in the pollen rain. The case of Castanea is notable. The nearest trees grow up to $900 \mathrm{~m}$ asl on the Val Camonica side, $450 \mathrm{~m}$ below Pian di Gembro. Castanea is well represented in the modern pollen rain at Pian di Gembro (mean value $>5.6 \%$ ), more than the other abundant pollen producers (Quercus and Corylus) growing at shorter distance from Pian di Gembro.

\section{Material and Methods}

In September 1998 three cores were drilled in the SW part of Pian di Gembro using a Streif Livingstone piston corer. The main core, which was used for pollen analysis and ${ }^{14} \mathrm{C}$ dating, was $9.5 \mathrm{~m}$ long. Coring operations were performed in an area that had never been affected by peat exploitation, so a complete stratigraphy was obtained (Table 2). 
Table 2. Lithostratigraphy of core PGB1, taken at Pian di Gembro

\begin{tabular}{|c|c|}
\hline Depth $(\mathrm{cm})$ & Sediment description \\
\hline $0-$ & Sphagnum peat \\
\hline $4-200$ & $\begin{array}{l}\text { brown peat, from medium to high degree of } \\
\text { decomposition, rich in Cyperaceae } \\
\text { macroremains. Conifer needles and wood } \\
\text { fragments are rare. }\end{array}$ \\
\hline $200-$ & brown peat with very few macroremains \\
\hline $343-$ & $\begin{array}{l}\text { brown peat with abundant macroremains } \\
\text { (Cyperaceae rootlets and stems, conifer } \\
\text { needles, Equisetum plants, seeds, etc.) }\end{array}$ \\
\hline $440-450$ & wood layer, with sparse matrix \\
\hline $450-570$ & $\begin{array}{l}\text { brown peat, extremely rich in macroremains } \\
\text { (mainly Cyperaceae) }\end{array}$ \\
\hline $570-805,5$ & $\begin{array}{l}\text { soft but compact gyttja, which becomes lighter } \\
\text { in colour with greater depth, poor in } \\
\text { macroremains. Sharp lower limit. }\end{array}$ \\
\hline $805,5-$ & light brown silt-gyttja. Sharp lower limit. \\
\hline $830-850$ & grey clay, without macroremains \\
\hline $850-$ & coarse sand \\
\hline $855-950$ & grey clay, without macroremains \\
\hline
\end{tabular}

Preparation of samples for pollen analysis followed standard methodology (including HF and acetolysis). 283 samples were analysed, a sum of at least 1,000 pollen grains (with a few exceptions for pollen-poor Late Glacial clay) being counted. Lycopodium tablets (Stockmarr 1971) were added to the sediment samples for estimation of pollen concentration (grains $/ \mathrm{cm}^{3}$ ). Identifications were made with reference to Moore et al. (1991), Punt and Blackmore (1976-1995), Reille (1992-1995) and the reference collection of the Institute of Plant Sciences of Bern. Nomenclature of pollen types follows ALPADABA (Alpine Palynological Database) and the spelling of plant names is according to Pignatti (1982). Identification of fossil stomata follows Trautmann (1953). Determination of species of Pediastrum is according to Komárek and Fott (1983).

Pollen diagrams (Fig. 7 and 8) were drawn using the program TILIA 1.11 (Grimm 1992). Pollen percentages are based on a pollen sum which includes trees, shrubs and upland herbs (Cyperaceae, aquatics and spores are excluded). The diagrams were then divided in LPAZ (local pollen assemblage zones).
Holocene chronozones follow Welten (1982), valid for the Alps and based on Mangerud et al. (1974). The Late Glacial is subdivided in Late Glacial Interstadial (LGI) and Younger Dryas. The interval preceding the LGI is, however, unnamed.

\section{Radiocarbon dating}

AMS ${ }^{14} \mathrm{C}$ dates on terrestrial plant remains were determined at the R.J. Van de Graaff Laboratorium (Faculteit Natuur- en Sterrenkunde, University of Utrecht, The Netherlands). The results, calibrated with the program CALIB 4.3 (Stuiver et al. 1998) are summarised in Table 3 and plotted in Figs. 7 and 8.

The age-depth curve can be roughly divided into three parts. The interval $801-701 \mathrm{~cm}$ covers about 3,600 years, during which the sedimentation rate was rather low (average of $0.28 \mathrm{~mm} /$ year). The interval $701-161 \mathrm{~cm}$ covers about 6,900 years; the sedimentation rate is higher than before (average of $0.87 \mathrm{~mm} /$ year) and apparently does not seem to have been influenced by the change of sediment type from gyttja to peat that occurred at $570 \mathrm{~cm}$ depth. A lower sedimentation rate (average of $0.55 \mathrm{~mm} /$ year) characterises the last 2 millennia. Unfortunately no ${ }^{14} \mathrm{C}$ dates are available for the interval between $945-801 \mathrm{~cm}$, but the low pollen concentration values recorded here point to a rather high sedimentation rate.

\section{Results and discussion: vegetational development and climate history at Pian di Gembro}

The data are presented in Fig. 7 and are interpreted and compared with neighbouring sites in the following sections which correspond to the pollen assemblage zones in the diagram.

\section{$L P A Z P G B-1$ (up to $895 \mathrm{~cm}$ )}

After the retreat of the LGM glaciers, during the Alpine deglaciation, a pioneer vegetation typical of a cold and steppic environment started to spread on the raw soils of Pian di Gembro. Herbaceous, anemophilous taxa (Artemisia, Chenopodiaceae, Gramineae, Asteroideae, and

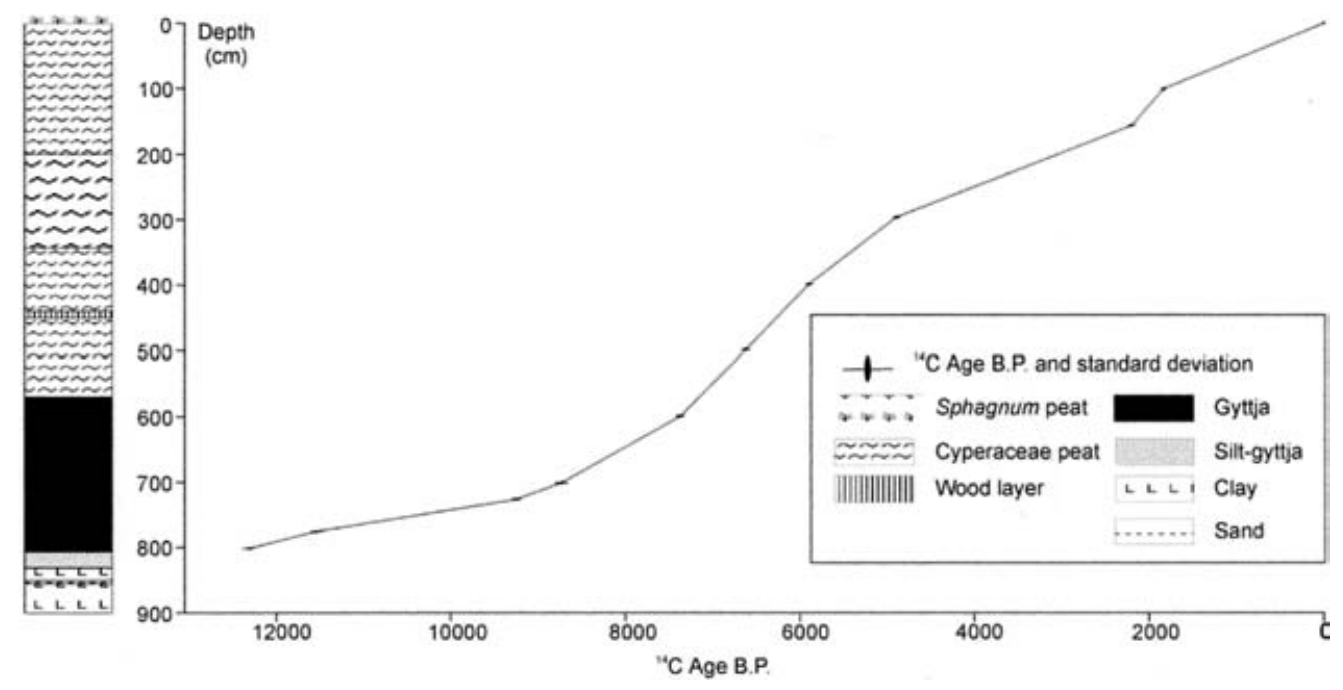

Fig. 6. Lithostratigraphic log of the core PGB1 taken at Pian di Gembro and age-depth model 
Table 3. AMS dates from Pian di Gembro

\begin{tabular}{|c|c|c|c|c|c|}
\hline Lab nr & Depth $(\mathrm{cm})$ & Analysed fraction & $\delta{ }^{13} \mathrm{C} \%$ & ${ }^{14} \mathrm{C}$ yrs B.P. & Calendar Age ( $1 \sigma$ range) \\
\hline UtC-9084 & $101-103$ & 4 leaves of Andromeda & -26.9 & $1,835 \pm 35$ & $1,821-1,712$ \\
\hline UtC-9082 & $297-303$ & needles of Picea & -26.7 & $4,895 \pm 40$ & $5,654-5,594$ \\
\hline UtC-9081 & $399-401$ & needles of Picea & -28.0 & $5,901 \pm 45$ & $6,780-6,772 ; 6,755-6,666$ \\
\hline UtC-9080 & $497-499$ & needles of Picea & -28.9 & $6,620 \pm 50$ & $7,568-7,524 ; 7,513-7,457 ; 7,451-7,432$ \\
\hline UtC-9078 & $701-703$ & twig of Betula & -29.8 & $8,730 \pm 70$ & $\begin{array}{l}9,889-9,878 ; 9,869-9,845 ; 9,835-9,830 ; 9,824-9,805 \\
9,799-9,554\end{array}$ \\
\hline UtC-9077 & 726 & $\begin{array}{l}1 \text { fruit of Tilia } \\
\text { platyphyllos }\end{array}$ & -25.9 & $9,250 \pm 50$ & $\begin{array}{l}10,500-10,435 ; 10,433-10,360 ; 10,344-10,328 \\
10,320-10,306 ; 10,306-10,285\end{array}$ \\
\hline UtC-9076 & $775-781$ & $\begin{array}{l}\text { fragments of bark and } \\
1 \text { seed of Pinus }\end{array}$ & -26.1 & $11,540 \pm 60$ & $13,793-13,666 ; 13,507-13,425$ \\
\hline
\end{tabular}

Cichorioideae, etc.) were present, together with a few shrubs (Ephedra distachya and E. fragilis type). Galium, Armeria, and Caltha were also present. A few pollen grains of Picea in the deepest part of the profile can be attributed to long-distance transport (Ravazzi 2002). The absence of conifer stomata and very low pollen concentration values of Pinus sylvestris/mugo and Pinus cembra suggest that transport from the pre-alpine valleys below is probably responsible for the presence of pine pollen in Pian di Gembro: at that time the timberline was still lower than $1350 \mathrm{~m}$ asl.

\section{$L P A Z P G B-2(895-838 \mathrm{~cm})$}

Pioneer herbaceous taxa still dominated the vegetation (e.g. Helianthemum, Saxifraga oppositifolia type, Plantago alpina, and $P$. lanceolata type). In addition, other taxa appeared in the pollen flora: Rumex acetosa type, Brassicaceae, Labiatae, Apiaceae (Anthriscus sylvestris type, Peucedanum palustre type, Carum carvi type). This higher biodiversity may indicate soil development (enrichment in organic matter) and possibly early climatic warming. Juniperus appeared in the vegetation. At lower altitudes reforestation started around 13,000 B.P., when Betula and Larix immigrated and spread (Gehrig 1997).

Percentages of birch pollen are quite low (0-3.3\%). Betula is well represented in the modern pollen rain at Pian di Gembro (between 7.6 and $16.6 \%$, only one sample records Betula pollen as low as 2.4\%: Table 1 ). According to these values, the local presence of Betula during this pollen zone is excluded.

The alpine belt, dominated by grasslands, extended above $1600 \mathrm{~m}$ (Gehrig 1997).

\section{$L P A Z P G B-3 a(838-800 \mathrm{~cm})$}

Several species of algae were present in the lake of Pian di Gembro (Pediastrum boryanum ssp. longicorne, Pediastrum integrum, rarely Pediastrum orientale, and Botryococcus pila): they suggest that the lake water was cold, clean, and oligotrophic/distrophic. Isoetes lacustris started. Among the aquatic and wetland species Thalictrum, Typha latifolia, Myriophyllum alterniflorum, Potamogeton, and Nymphaea were present.

The comparison of percentage values of Betula in the pollen diagram (2.4-27\%) with those in the modern pollen rain at Pian di Gembro (mean value $=11.4 \%$ ) indicates that birch had reached the plain of Pian di Gembro, developing a shrub vegetation together with Hippophae and Salix. The occurrence of Betula near the basin is also demonstrated by a fragment of twig found between 801-803 $\mathrm{cm}$ and dated to $12,320 \pm 60$ B.P.

The rise of NAP values during this pollen zone may indicate the development of species-rich meadows. The percentage rise is mainly due to Artemisia (which reaches $40 \%$ ) and to a lesser extent to Gramineae, Asteroideae (Aster type, Centaurea scabiosa, Cirsium) and Cichorioideae. The phase recorded between $830-804 \mathrm{~cm}$ at Pian di Gembro could have been induced by a climatic change that favoured the expansion of herbaceous vegetation. This phase predates the Bighera oscillation, defined by Gehrig (1997) as a recession of Pinus values, rise of NAP pollen, and increase of minerogenic components in the sediment. The Bighera oscillation is not clearly recognizable in the pollen diagram from Pian di Gembro. The climatic phase recorded at Pian di Gembro could be correlated with the moderate expansion of Pinus cembra and Betula recorded before 12,340 B.P. at Lago di Annone (226 m asl, N Italy), just before the strong expansion of pine documenting the beginning of the Late Glacial interstadial including the Bølling and Allerød (Wick 1996).

Alnus viridis spread earlier in Val Camonica than in localities situated north of the Alps (for instance in Engadine and in the Grisons), suggesting the occurrence of green alder south of the Alps during the Alpine deglaciation. In pollen diagrams from Engadine and

Fig. 7. Percentage pollen diagram of selected taxa from Pian di Gembro. Pollen percentages are based on a pollen sum which includes trees, shrubs and upland herbs (Cyperaceae, aquatics and spores are excluded). Pollen influx, pollen concentration, and charcoal concentration curves are also plotted. Unless otherwise stated, curves are exaggerated $\times 5$ : exaggeration is indicated by stippling. Curves of Pediastrum, Isoetes, Sphagnum, Tilletia sphagni, and Amphitrema are exaggerated x3 


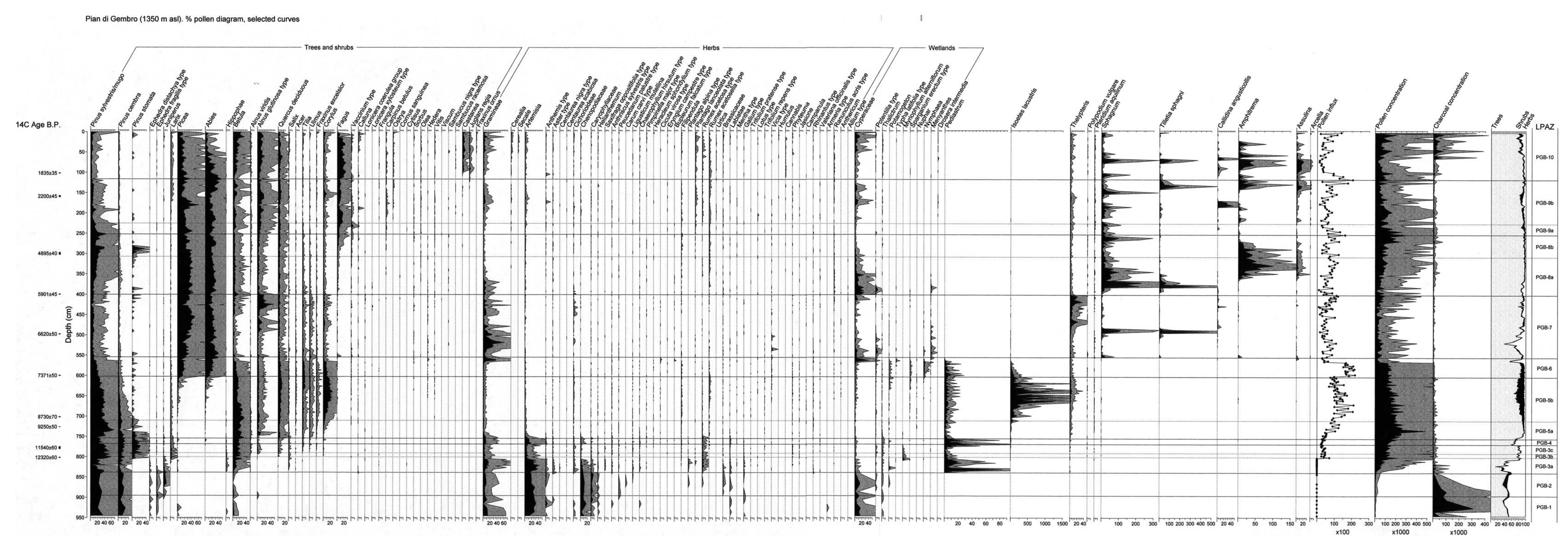


Grisons (Burga 1980, Burga 1987; Zoller et al. 1996), Alnus viridis is recorded only from the Atlantic onwards with the continental climate of central alpine valleys playing an important role in controlling its spread. However, Alnus viridis never reached high percentage values in Pian di Gembro $(<5 \%)$, probably due to the relatively low elevation of this site, while on the contrary, at Col di Val Bighera (2087 m asl; Gehrig 1997) it reached values of $10-20 \%$.

LPAZ PGB-3b (800-790 cm, 12,300-12,000 B.P., beginning of Late Glacial interstadial)

This pollen zone is characterised by the arrival and subsequent mass expansion of Pinus sylvestris/mugo and Pinus cembra, dated to $12,320 \pm 60$ B.P., as indicated by the presence of stomata and high percentage and concentration values. Betula and Larix were also present. Heliophilous taxa (Artemisia, Chenopodiaceae, and Ephedraceae), previously abundant, decreased locally and moved to higher altitudes.

At Palu' di Edolo, $700 \mathrm{~m}$ below Pian di Gembro and 10 $\mathrm{km}$ away, the immigration of Pinus sylvestris/mugo and Pinus cembra occurred around 13,000 B.P. (Gehrig 1997). The presence of Pinus sylvestris/mugo, Pinus cembra, and Larix was observed for the pre-alpine belt by Orombelli and Ravazzi (1995) and at Cerete Basso (440 m asl, Val Borlezza, prov. of Bergamo) conifer forests were already established at $13,025 \pm 150$ B.P. A certain delay in the altitudinal expansion of Larix is seen in most of the pollen diagrams from the Grisons (Switzerland: Burga 1982), where it appeared at $1900-2000 \mathrm{~m}$ asl during the Preboreal.

LPAZ PGB-3c (790-768 cm, 12,000-11,000 B.P., second part of the Late Glacial interstadial)

During this period pine, larch and birch forests were present in Pian di Gembro. The pollen diagram records the presence of pollen of Quercus $(0.4-2.8 \%)$, Tilia $(0-1 \%)$, Ulmus $(0-1.3 \%)$ and Fraxinus excelsior $(0-0.8 \%)$. The comparison of the percentage values of these mesic taxa and the modern pollen rain at Pian di Gembro are compatible with the presence of Quercus, Tilia and Ulmus at lower altitude, in the montane belt. Fraxinus excelsior must have been either still very far from Pian di Gembro or represented in the lowlands by few trees.

Heliophilous shrubs (e.g. Juniperus, Ephedraceae, and Hippophae) quickly decreased. These features point to an improvement of the environmental conditions.

As already stated for Alnus viridis, Pinus cembra spread later in Engadine than in Val Camonica. In the pollen diagram from Chanoua (1590 $\mathrm{m}$ asl; Zoller et al. 1996) the species is recorded from the Allerød onwards. Thus the reimmigration into Engadine from northern Italy, postulated by Zoller et al. (1996), does seem probable.

LPAZ PGB-4 (768-754 cm, 11,000-10,000 B.P., Younger Dryas)

In this zone rapid cooling had strong effects on the vegetation: Pinus sylvestris/mugo (but not Pinus cembra) quickly decreased, and the steppe vegetation, typical of the Oldest Dryas, spread again. Artemisia, Chenopodia- ceae, Helianthemum, Saxifraga oppositifolia type, Brassicaceae and other herbaceous taxa that had moved to higher altitudes during the Allerød, moved downwards again and colonized the open areas. A reduction phase in mixed oak taxa also testifies to the cooling and the dryness of this period. The climatic deterioration of the Younger Dryas is also well represented in the pollen zone DA 3 of the diagram from Selva (Poschiavo, $1440 \mathrm{~m}$ asl; Burga 1987), where the strong expansion of steppic elements led to a reduction in former pine stands.

Pollen diagrams from the south pre-alpine border (Lago di Annone and Lago del Segrino, Brianza; Wick 1996) testify to a tripartite structure for the Younger Dryas, probably representing different climatic conditions affecting thermophilous taxa (Ulmus, Tilia, Quercus, etc), which did not have the same significance at the altitude of Pian di Gembro.

In the stratigraphical sequence from Pian di Gembro, the Younger Dryas is represented by only $14 \mathrm{~cm}$ (754-768 $\mathrm{cm})$, thus indicating a low sedimentation rate. The thin layer representing the Younger Dryas in Pian di Gembro makes it difficult to investigate in detail whether the above-mentioned tripartite structure is present or not, but it seems rather probable that the division is missing. Low sedimentation rate during the Younger Dryas is common to several pollen records from Northern Italy (Palù di Edolo, Tonale, Col di Val Bighera, Gehrig 1997; Cerete Basso, Orombelli and Ravazzi 1995; Lago di Ganna, Schneider and Tobolski 1985) and is usually related to low precipitation and reduced detrital supply to lacustrine basins.

\section{LPAZ PGB-5a (754-710 cm, 10,000-9,000 B.P., Preboreal)}

The Preboreal is marked by a large expansion of mixed oak forest taxa. Forests of Quercus, Tilia (T. cordata and T. platyphyllos), Ulmus and Acer developed at the altitude of Pian di Gembro. This hypothesis is corroborated by the comparison of percentage pollen data from this pollen zone and the modern pollen rain. Pollen of these mesic trees is poorly represented in the pollen traps placed at Pian di Gembro (Quercus is between 0-2.3\%, Tilia 0.1 $0.3 \%$, Ulmus $0.1-0.3 \%$ and Acer $0-0.1 \%$ ), although these species are very abundant in the lower vegetational belts. The higher percentage values recorded in this pollen zone could therefore be compatible with the presence of Quercus, Tilia, Ulmus and Acer at the altitude of Pian di Gembro during this period. The occurrence of Tilia platyphyllos near the basin is demonstrated by a fruit found at $726 \mathrm{~cm}$ depth and dated to $9,250 \pm 50$ B.P. Betula, Pinus sylvestris/mugo, Pinus cembra, and Larix (whose stomata were found in the sediment) were also present in the nearby forests. Calluna, Vaccinium, and Lonicera coerulea were part of the local vegetation; Juniperus became more and more discontinously present. Among the herbs, species belonging to Potentilla type, Rumex acetosa and $R$. acetosella type, Rhinanthus type, Filipendula, Phyteuma, and several of the Apiaceae grew around the lake. 
LPAZ PGB-5b (710-602 cm, 9,000-7,400 B.P., Boreal/Atlantic)

Corylus expansion is dated to about $9,250 \pm 50$ B.P., even though its maximum spread took place later, during the Boreal. Frangula and Sorbus made up part of the forest composition. The constant presence of Hedera points to mild winters. Among the herbaceous taxa, Rumex acetosa and $R$. acetosella type, Vicia type, Phyteuma, and Rhinanthus type were still rather abundant. Potamogeton, Sparganium erectum type, Nuphar, and Nymphaea grew in the lake of Pian di Gembro. Pinus sylvestris/mugo declined, although still present (stomata). Pinus cembra had definitively left Pian di Gembro moving to higher altitudes near the timberline as its presence is recorded in the pollen diagram from Col di Val Bighera (Gehrig 1997), where it formed dense forests together with larch and birch. Nowadays Pinus cembra is present in restricted areas in Val Camonica and the northern side of the Orobian Alps (Arietti 1978; Armiraglio et al., in prep.) and is more abundant in the nearby Valtellina, where it forms mixed stands with Picea abies and Larix decidua (Piussi 1992).

\section{LPAZ PGB-6 (602-554 cm, 7,400-7,000 B.P., early Atlan- tic)}

A rapid and simultaneous expansion of Picea and Abies is dated to $7,371 \pm 50$ B.P. $(8,059-8,274$ cal B.P. $)$ around Pian di Gembro, and competition between mixed oak taxa and conifers caused a slight but general decrease of the former. A similar immigration pattern for Picea and Abies can be recognized in the pollen diagram of Selva (Burga 1987).

The strong resemblance between the curves of Picea and Abies, their sudden expansion, and the related vegetational changes that occurred in less than 100 years are astonishing. This event, which cannot be considered an artifact of the percentage decrease in other taxa (cf. concentration curve, Fig. 8), involves two species that have different biogeographic histories. At 7,300 B.P./8,200 cal B.P. a sharp and irreversible transition from a dry to a wetter Holocene took place on a global scale (Blunier et al. 1995). Increasing humidity at Pian di Gembro favoured the expansion of Picea and Abies, which found new areas for colonization, forming a new altitudinal vegetational belt, the montane coniferous forests. Picea forests were already established at higher altitudes (Col di Val Bighera, Gehrig 1997) at 8,300 B.P.; from these, Picea moved to colonize the areas at the montane altitude of Pian di Gembro.

Abies was already present in the lowland at around 9,000 B.P., being part of the local forests at around 7,600 B.P. (Lago di Annone: Wick 1996). The increasing humidity at $8,200 \mathrm{cal} \mathrm{B.P.} \mathrm{gave} \mathrm{these} \mathrm{the} \mathrm{chance} \mathrm{to} \mathrm{expand} \mathrm{at}$ middle altitudes, thus reaching Pian di Gembro (1350 m asl, 7,370 B.P.) and Palu' di Edolo (650 $\mathrm{m}$ asl, 7,285 B.P.).

\section{LPAZ PGB-7 (554-400 cm, 7,000-5,900 B.P., middle At- lantic)}

During early Atlantic, the development of the lake of Pian di Gembro into a peat mire took place. The change from fine detritus gyttja to peat, the decrease in pollen from aquatic taxa (Myriophyllum alterniflorum, Nuphar,
Nymphaea) and the increase in pollen of mire species (Menyanthes, Drosera intermedia) suggest the transition from a limnic to a telmatic environment. The rise in the curve of Potentilla type (probably $P$. erecta or $P$. palustris) indicates the local development of fen peat. Nowadays Potentilla erecta and P. palustris are largely scattered in the local vegetation at Pian di Gembro, occurring respectively in Molinia- and Trichophorum-dominated vegetation ( $P$. erecta) and Carex- and Sphagnumdominated vegetation ( $P$. palustris). An important change in the algal assemblage indicates this transition: different species of Pediastrum and Botryococcus (Pediastrum angulosum var. angulosum and Botryococcus neglectus) replaced the previous ones, indicating mesotrophic waters and a change to mire conditions. The first important peaks in Sphagnum and Tilletia sphagni occurred at around $6,620 \pm 50$ B.P. Gramineae and Cyperaceae quickly colonized the borders of the peat fen.

During middle Atlantic the slopes surrounding Pian di Gembro were covered by conifer forests, which probably reached to the margins of the peat mire (abundant stomata were found in the sediment). A long phase dominated by Alnus glutinosa type started at 6,620 50 B.P., ending at $5,901 \pm 45$ B.P.; Betula expanded, even if not as rapidly as Alnus. Hedera was often present. Viscum pollen is recorded from one sample; this could be an indication of rather warm summers (around $16-18{ }^{\circ} \mathrm{C}$ ) and quite cold winters (no colder than $-6^{\circ} \mathrm{C}$ ).

LPAZ PGB-8a (400-307 cm, 5,900-5,000 B.P., later Atlantic)

During the middle Neolithic the first signs of human activity had already appeared. The presence of meadows and pastures around the mire of Pian di Gembro is suggested by the percentages curves of Rumex acetosa and $R$. acetosella type, and Ranunculus acris type. Clear proofs of stable human settlements in the vicinity of Pian di Gembro are missing, but the existence of these, probably not too far from the site, is indicated by findings of Cerealia pollen grains. The nearest coeval populations were the Camuni, several settlements of whom were found along Val Camonica (the name of which is derived from this ancient population). Their rock engravings cover a long period of time, from the Epipalaeolithic to the Roman Conquest (1st cent. AD) (Anati 1975; De Marinis 1989).

\section{LPAZ PGB-8b (307-252 cm, 5,000-4,100 B.P., early Subboreal)}

The first occurrence of single pollen grains of Fagus in the pollen diagram from Pian di Gembro is dated to approximately 8,500 B.P. The percentage curve is discontinuous for about 2,600 years $(705-398 \mathrm{~cm})$, eventually becoming continuous at $398 \mathrm{~cm}$, thus underlining the gradual but progressive approach of Fagus to Pian di Gembro. The expansion of Fagus in the vicinity of Pian di Gembro is dated to $4,895 \pm 40$ B.P., and took about 900 years (300$250 \mathrm{~cm}, 4,895-4,000$ B.P.). Beech immigration took place

Fig. 8. Pollen concentration diagram of selected trees, shrubs, herbs, spores, and other microfossil types from Pian di Gembro. Exaggeration $x 3$ is indicated by stippling. A charcoal concentration curve is also plotted 


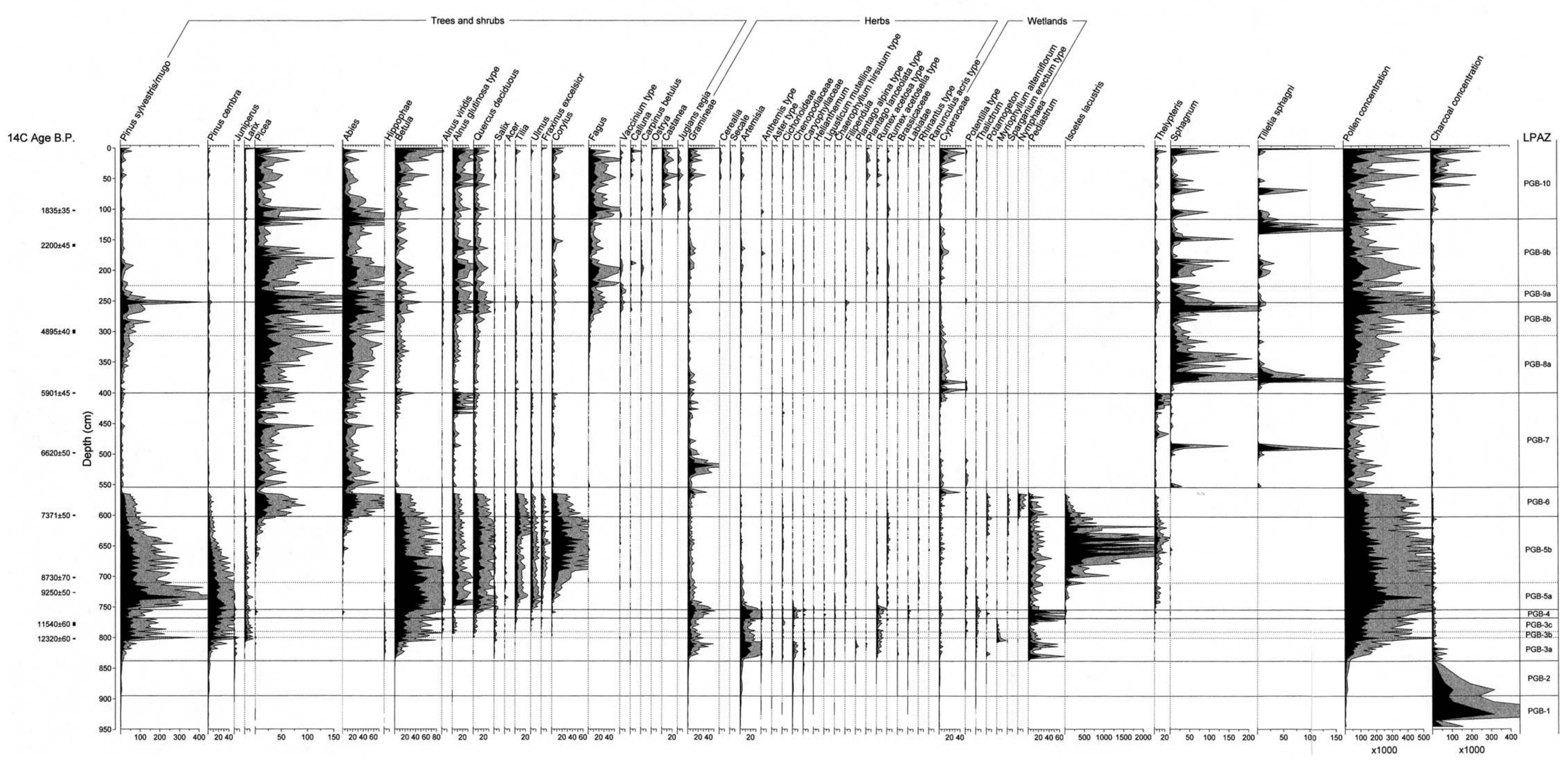


extremely slowly, but once established the species was able to thrive for several millennia. Similar results were obtained at Gola di Lago (Zoller and Kleiber 1971).

Fagus-dominated forests were growing in the plain of Pian di Gembro during the Subboreal and included Sambucus nigra type and Sorbus. Conifer forests (Picea, Abies, and Pinus sylvestris/mugo) covered the slopes at higher altitudes. Pinus cembra was absent in the local vegetation, very low pollen percentage values suggesting long-distance transport.

\section{LPAZ PGB-9a (252-225 cm, 4,100-3,700 B.P., later Subboreal)}

During the Bronze Age an increase in charcoal particles in the sediment seems to suggest an increase in human activities, with forest clearance starting locally in order to provide new areas for settlements, cultivation, grazing and wood for construction and fuel. Larix meadows (a form of grazed forest important in the central and southern Alps) started to spread. It is interesting to compare the relatively late human impact on vegetation, as seen in Pian di Gembro, with earlier anthropic activities. At Chanoua (1590 $\mathrm{m}$ asl, lower Engadine; Zoller et al. 1996), the spread of Larix meadows is dated to 4,820 B.P., simultaneous with a phase of anthropic cutting of Picea. Larix suddenly rose, reaching the highest pollen percentage within the whole section. In the following LPAZ, Picea quickly recovered, but Larix was still well represented (always about $10 \%$ ).

In Pian di Gembro the opening of the forests due to human activities led to a new expansion of herbs, typical of naturally open areas (Potentilla type, Filipendula, Rumex acetosa and $R$. acetosella type, Brassicaceae, Ranunculaceae, Rhinanthus type, etc.). Thelypteris, Polypodium vulgare, and Pteridium aquilinum were constantly present. Although clearly visible, the rise of NAP in Pian di Gembro is not really comparable with those observed in the vicinity of archaeological sites, where NAP can reach $40-50 \%$ of the whole pollen assemblage and where charcoal layers are found (e.g. Bedrina Leventina, $1235 \mathrm{~m}$ asl, Tessin, Zoller 1960; lower Engadine, Zoller et al. 1996).

\section{LPAZ PGB-9b (225-116 cm, 3,700-1,900 B.P., Subboreal/Subatlantic)}

Human impact increased during the Subatlantic. During the Iron Age, the slopes surrounding Pian di Gembro were used as pastures for cattle, as shown by the rise of shrubs and NAP (mainly Plantago lanceolata type, Rumex acetos $a$ and $R$. acetosella type, Ranunculus acris type, Urtica, Cannabis, Humulus - all indicators of cultivation, grazing and ruderal communities). Cereal cultivation developed. Deforestation led to the reduction of arboreal taxa such as Abies, Fagus, Ulmus, Tilia and, to a lesser degree, Acer and Fraxinus excelsior. These events can be easily correlated with the increasing curve of charcoal concentration. The decline in elm, lime, maple, ash, and ivy simultaneously with the evidence of farming activity points to the interference of humans with the vegetation. The wood from these taxa could be used for fuel and construction, and the flowers, leaves, and twigs for fodder (Troels-Smith 1960).
At around 2,200 \pm 40 B.P., larch meadows extended in the vicinity of Pian di Gembro, taking the place of the former pine stands; Ephedraceae and Juniperus appeared again in the pollen flora. The rising anthropic influence on the natural environment at lower altitudes is recorded by the expansion of taxa that could better withstand it. Thus Carpinus betulus showed its maximum abundance in early Subatlantic, and also Corylus, even if for a short period, took advantage of this situation. The spread of Ostrya was also influenced by human activity. The same pattern is described by Küster (1997) for central Europe.

\section{$L P A Z$ PGB-10 (from $116 \mathrm{~cm}$ and 1,900 B.P. up to the present time, Subatlantic)}

The introduction of Castanea and Juglans, dated to $1,835 \pm 35$ B.P., marked the beginning of the Roman period. The continuous curves of Larix and anthropogenic indicators point to intensive grazing. The forests were not yet heavily exploited; only the percentage values of Abies decreased sharply, followed by an increase of charcoal particles in the sediments. The question as to whether such southern-alpine Abies declines were caused by fire or by other factors (the fires occurring soon after) is currently under study (Mohl and Wick, in prep.; Keller et al., in prep.).

Intensive clearings are documented since the Middle Ages at every altitude, not only for agricultural purposes and fuel. The existence of several iron-smelting sites in Val Camonica and its lateral valleys (Cucini Tizzoni and Tizzoni 1996; Gehrig 1997; Marziani and Citterio 1999) could explain the urgent need for wood. Abies and Fagus decreased, and the concentration of charcoal particles in the sediments increased. Indicators of grazing and pasture were still well represented. Cereal cultivation increased, the record of Secale starting here. In the last 50-100 years Pinus sylvestris/mugo has spread again, probably due to the reduction in other woody taxa such as Abies, Picea, and Fagus.

\section{Other microfossil analysis}

Several microfossil types (according to van Geel 1978) were identified in the pollen slides (Fig. 7). The records of some Protozoa offer additional information on the environment and the trophic state of the water.

Remains of Amphitrema and Assulina (types 31A and 32; van Geel 1978) appear in the pollen record from Pian di Gembro after the development of the lake into a peat mire had taken place. Both are indicators of oligotrophic conditions, their abundance pointing to locally wet conditions, low values indicating locally dry conditions. The rhizopod Arcella (type 352; van Geel 1978) is also a lownutrient indicator, however it is incompletely recorded due to its destruction by acetolysis. Loricae of Callidina angusticollis (type 37; van Geel 1978) are found in the uppermost $550 \mathrm{~cm}$ of the section; this species of Rotifera seems to prefer birch carr as a habitat (van Geel et al. 1981).

\section{Accumulation rates}

In order to estimate the sedimentation rates correctly, a comparison between the age-depth model and the pollen concentration curve is needed. In fact, the numerical val- 
ues obtained by dividing the $\Delta^{14} \mathrm{C}$ yrs B.P. and the $\Delta$ depths for every stratigraphic interval are simply mean values, not taking into account differences in the accumulation processes which are better described by the pollen concentration curves (Figs. 7, 8). Middeldorp (1982) showed that in peat bogs under densely forested conditions (e.g. early Holocene succession in Central and Southern Europe) the AP influx is fairly constant so this feature may be used for a detailed evaluation of the sedimentation rate through lithological changes.

Considering in particular the interval $500-600 \mathrm{~cm}$ in the sequence from Pian di Gembro, the estimated sedimentation rate is about $1.3 \mathrm{~mm} /$ year $(100 \mathrm{~cm}$ in 750 years $)$. The total pollen concentration curve (Fig. 7) for the same interval shows high values from $570-600 \mathrm{~cm}$ and then decreases sharply by a factor of 3 . Assuming that AP pollen concentration during this forested interval is dependant on the sedimentation rate (and the latter on the different accumulation processes), we can infer a sedimentation rate for the interval $500-570 \mathrm{~cm}$ that was about 3 times higher than that at $570-600 \mathrm{~cm}(1.95 \mathrm{~mm} /$ year and $0.65 \mathrm{~mm} /$ year $)$. This pattern perfectly fits with the lithological sequence; at a depth of $570 \mathrm{~cm}$, lake gyttja is replaced by peat, this generally accumulating faster than gyttja.

During LPAZ PGB-1 and PGB-2 pollen concentration shows the lowest values (between 887-5,809 grains $/ \mathrm{cm}^{3}$ ). In these cases, both a high sedimentation rate and a poor pollen influx (mainly of herbaceous taxa) could explain such low values. Pollen concentration rises during LPAZ PGB-3, when reforestation took place with the increased vegetation cover leading to increased pollen production and influx. Pinus sylvestris/mugo and Pinus cembra present in Pian di Gembro strongly contribute to pollen concentration in the sediment; this can quickly rise to around 200,000 grains $/ \mathrm{cm}^{3}$.

Pollen concentration shows high values in LPAZ PGB4 (corresponding to the Younger Dryas: 134,000-211,000 grains $/ \mathrm{cm}^{3}$ ) and PGB-5 (constantly above 100,000 grains/ $\mathrm{cm}^{3}$ with a peak of 490,000 grains $/ \mathrm{cm}^{3}$ recorded at $734 \mathrm{~cm}$ depth). During LPAZ PGB-6 pollen concentration and influx decrease sharply at $570 \mathrm{~cm}$, reaching minimum values of 30,000 grains $/ \mathrm{cm}^{3}$. As previously stated, these parameters are influenced by the change of sediment (from lake gyttja to peat) occurring here, which has the effect of 'diluting' pollen. In LPAZ PGB-7 and PGB-8 (up to $280 \mathrm{~cm}$ ) pollen concentration shows values lower than 80,000 grains $/ \mathrm{cm}^{3}$. At $280 \mathrm{~cm}$ it rises quickly, due to a local expansion of Pinus sylvestris/mugo (the stomata of which were abundant in pollen slides); the same pattern can be observed in the influx curve. In LPAZ PGB-9 high values of pollen concentration are recorded up to $188 \mathrm{~cm}$, above this they decline to between $20,000-80,000$ grains $/ \mathrm{cm}^{3}$. Only in the upper $20 \mathrm{~cm}$ (LPAZ PGB-10) are high values of pollen concentration $\left(108,000-253,000\right.$ grains $\left./ \mathrm{cm}^{3}\right)$ again recorded.

The increase in pollen concentration recorded in LPAZ PGB $3 b$ is influenced by the change of sediment type that occurred at $830 \mathrm{~cm}$. However increasing pollen concentration in LPAZ PGB 5a is instead the reaction of the vegetation to the climatic warming that marks the beginning of the Holocene. This climatic amelioration led to phases of both denser vegetation and higher pollen productivity.

\section{The event at 8,200 cal B.P.}

It is possible to see a striking correspondence between the simultaneous expansion of Picea and Abies at Pian di Gembro and the major Holocene climatic change recorded in the GRIP ice core from central Greenland as a strong fluctuation of atmospheric methane concentration (Blunier et al. 1995). The GRIP curve of methane concentration shows a sharp decrease at around $8,200 \mathrm{cal}$ B.P., which equals about 7,500 B.P.; a similar feature is also present in the isotope record. Chappellaz et al. (1993) supposed that low-latitude moisture fluctuations could be partly responsible for the changes of atmospheric methane concentration. Blunier et al. (1995) underline that during the Holocene the lowest methane concentrations are contemporaneous with droughts in the tropics. Atmospheric methane concentration increased during late Holocene, probably due to a larger contribution from northern wetlands.

Stable oxygen isotope ratios in ostracods from Lake Ammersee (southern Germany; von Grafenstein et al. 1998 ) indicate a 200 -year long negative excursion which is contemporaneous with the $\delta^{18} \mathrm{O}$ excursion in the GRIP ice core dated 8,200 cal B.P. Von Grafenstein et al. (1998) interpreted this isotopic signal as induced by a perturbation of the North-Atlantic thermohaline circulation, possibly triggered either by a weak forcing or by a freshwater pulse due to the decay of the Hudson Bay Ice Dome.

In the pollen diagram from Pian di Signano $(1540 \mathrm{~m}$ asl, Switzerland: Zoller 1960) strong depressions of the Abies belt, occurring between 7,500-6,500 B.P., were interpreted as being caused by the 'Misox cold phase'. Zoller et al. (1966) postulated that such a climatic phase was not limited to the Alps and proposed a correlation with glacier advances in North America. The strong climatic deterioration referred to as 'Misox oscillation' is represented in the palaeobotanical investigations at Lago Basso $(2250 \mathrm{~m}$ asl $)$ and Gouillé Rion (2343 m asl) (respectively Italy and Switzerland; Wick and Tinner 1997) as marked timberline oscillations, and at Wallisellen-Langachermoos (Switzerland; Haas 1996) as the abrupt decline in the frequency of Najas seeds.

Data indicate the presence and the stability of Picea, between 8,500-9,000 B.P., at altitudes near or above 1800 $\mathrm{m}$ asl in the Central Alps (Fig. 1a) (Ravazzi 2002). At 9,000 B.P. Picea was at Pian Venezia $(2270 \mathrm{~m}$ asl, Val di Sole; Speranza et al. 1996); at 8,300 B.P. Picea was present at Col di Val Bighera (2087 m asl; Gehrig 1997); at 8,200 B.P. it was at Passo del Tonale $(1883 \mathrm{~m}$ asl; Gehrig 1997) and not far from Pian dei Cavalli (2250 m asl; Wick 1994). These data suggest that during this time interval, Picea remained at high altitudes, where climatic and edaphic conditions were favourable for its survival and spread.

There are also indications of the early presence of Abies in the lowlands of Lombardy. At 10,500 B.P. the percentage curve of Abies at Lago di Annone and Lago del Segrino (226 m and $374 \mathrm{~m}$ asl; Wick 1996) became continuous. Abies was present as single trees up to 7,600 B.P., when it started being part of the local forests.

Methane concentration is correlated to air humidity: changes of humidity can modify the amplitude of a vegetational belt, thus favouring the immigration and expansion of taxa already present in nearby belts. An increase in humidity that occurred at 8,200 cal B.P. could 
therefore be responsible for the spread, at middle and low altitudes of Picea, which reached Pian di Gembro at 7,370 B.P. (this work) and Palu' di Edolo at 7,285 B.P. (Gehrig 1997). The same mechanism could explain the expansion of Abies from the lowlands toward middle and high altitudes.

This transition occurring at $8,200 \mathrm{cal}$ B.P. marked the end of the continental climatic regime and led to moister climatic conditions. Tinner and Ammann (2001) suggest that the transition was probably caused by an increase in the amount of humid air masses coming from west and north-west, resulting in the lowering of summer and winter temperatures and increased precipitation.

It is difficult to say if the sudden spread of Picea and Abies, as documented by the pollen record of Pian di Gembro, is just a response to a climatic change. Modern knowledge about migration routes after the LGM can be still improved, offering additional elements to answer this question. Several other factors should be mentioned as having played a role in determining the spread of Picea and Abies at the altitude of Pian di Gembro. These are the presence of soils already developed under forest cover, the absence of viable competitors and humidity and temperature conditions.

\section{Conclusions}

A high-resolution pollen analysis at Pian di Gembro (1350 $\mathrm{m}$ asl, Central Alps, Northern Italy) documents the history of vegetation and climate in detail, allowing comparisons with neighbouring sites at different altitudes. ${ }^{14} \mathrm{C}$ chronology offers a reliable time resolution. The results of this research can be summarised as follows:

1. After the retreat of glaciers after the Last Glacial Maximum, pioneer plants (mainly herbaceous taxa) spread in the plain of Pian di Gembro. The first shrub vegetation (Juniperus, Alnus viridis, Salix, Ephedraceae) seems to have expanded well before the beginning of the Late Glacial Interstadial, despite the lack of a chronological frame for this event.

2. The arrival and expansion of Pinus sylvestris/mugo and Pinus cembra in Pian di Gembro are dated to 12,320 B.P.

3 . The rapid cooling of the Younger Dryas strongly reduced the extent of Betula-Pinus forests, and a fresh expansion of steppe vegetation occurred. Low precipitation and reduced detrital supply into the lacustrine basin could explain the low sedimentation rate during this event.

4. The large and rapid expansion of mixed oak forest taxa in Pian di Gembro took place during the Preboreal. Broad leaved trees reached higher altitudes suggesting milder winter temperatures at the beginning of the Holocene.

5. The sudden and simultaneous expansion of Picea and Abies is dated to 7,370 B.P., about 8,200 cal B.P., recording a clear, abrupt change in the structure of vegetational belts. This climatic change as evidenced in the polar ice cores was also detected through oscillations of the timberline (Zoller 1960; Wick and Tinner 1997). Pian di Gembro offers the first palynological evidence of the wide impact of this climatic change on a middle-altitude environment.

6. The development of the lake of Pian di Gembro into a peat mire, which took place during early Atlantic, is re- vealed by sedimentological and local pollen-assemblage changes.

7. Human impact is well documented since the middle Neolithic, and increased during the Iron Age and Roman Period, when pasture lands were present in the surroundings of Pian di Gembro. From the Middle Ages onwards, the activity of iron smelting sites, wide-spread in Val Camonica, led to heavier exploitations of the forests.

8. In the last century the decrease of Abies, Picea, and Fagus led to a new expansion of pine forests.

Acknowledgements. I wish to thank W. Tanner, L. Wick, C. Mangili, C. Ravazzi, Prof. C. Andreis, J.F.N. van Leeuwen, W. Tinner, V. Jankovska, and A. Bertolini for their support. ${ }^{14} \mathrm{C}$ datings were funded by the Institute of Plant Sciences, University of Bern and C.N.R. - Istituto per la Dinamica dei Processi Ambientali of Milano (Prof. B. Ammann and P.M. Rossi). Thanks are due to Prof. H. Zoller and L. Wick for fruitful discussions of the pollen diagrams and to Prof. B. Ammann and C. Ravazzi, who read a first draft of the manuscript and greatly improved its quality. Prof. H.E. Wright jr. is gratefully acknowledged for corrections on the English text. This study was undertaken thanks to a grant-in-aid given to the author by the University of Milano for a stay at the Institute of Plant Sciences, University of Bern. The accurate revision by $\mathrm{R}$. Drescher-Schneider is kindly acknowledged, as well as comments by Prof. C. Burga.

\section{References}

Anati E (1975) Evoluzione e stile nell'arte rupestre camuna. Archivi, Capo di Ponte, 6

Andreis C, Pini R, Ravazzi C, Sala E, Wick L (1999) La torbiera di Pian di Gembro (Alpi Centrali): dinamica attuale e storia della vegetazione nell'Olocene superiore. Congresso della Società Botanica Italiana, abstracts: 18

Andreis C, Rodondi G (1982) La Torbiera di Pian di Gembro (Prov. di Sondrio). Collana del programma finalizzato 'Promozione della qualità dell'ambiente', Consiglio Nazionale delle Ricerche, Roma

Arietti N (1978) La distribuzione del cembro nelle Alpi bresciane. Natura Bresciana 9: 35-56

Blunier T, Chappellaz J, Schwander J, Stauffer B, Raynaud D (1995) Variations in atmospheric methane concentration during the Holocene epoch. Nature 374: 46-49

Burga CA (1980) Pollenanalytische Untersuchungen zur Vegetationsgeschichte des Schams und des San Bernardino-Passgebietes (Graubünden, Schweiz). Dissertationes Botanicae 56, J. Cramer, Vaduz

Burga CA (1982) Pollenanalytical research in the Grisons (Switzerland). Vegetatio 49: 173-186

Burga CA (1987) Gletscher- und Vegetationsgeschichte der Südrätischen Alpen seit der Späteiszeit. Denkschriften der Schweizerischen Naturforschenden Gesellschaft 101.

Chappellaz J, Blunier T, Raynaud D, Barnola JM, Schwander J, Stauffer B (1993) Synchronous changes in atmospheric $\mathrm{CH}_{4}$ and Greenland climate between 40 and 8 kyr B.P. Nature 366: 443-445

Credaro V, Pirola A (1975) La vegetazione della provincia di Sondrio. Amministrazione Provinciale di Sondrio

Cucini Tizzoni C, Tizzoni M (1996) Un impianto siderurgico di epoca longobarda nelle Alpi bresciane: Ponte di Val Gabbia I Bienno (Brescia). Rassegna di Studi del Civico Museo Archeologico e del Civico Gabinetto Numismatico di Milano 58: $47-76$

Dal Piaz GB (1929) Relazione geomorfologica sulla palude di Pian di Gembro. Unpublished 
Fedele F, Wick L (1996) Glacial/Postglacial transition south of Splügen Pass: environment and human activity. Il Quaternario 9: $541-550$

Geel B van (1978) A paleoecological study of Holocene peat bog sections in Germany and The Netherlands, based on the analysis of pollen, spores and macro- and microremains of fungi, algae, cormophytes and animals. Review of Palaeobotany and Palyno$\operatorname{logy} 25: 1-120$

Gehrig R (1997) Pollenanalytische Untersuchungen zur Vegetations- und Klimageschichte des Val Camonica (Norditalien). Dissertationes Botanicae 276. J. Cramer, Berlin Stuttgart

Geel B van, Bohncke SJP, Dee H (1981) A palaeoecological study of an upper Late glacial and Holocene sequence from 'De Borchert', The Netherlands. Review of Palaeobotany and Palyno$\log$ 31: 367-449

Grafenstein H van, Muller J, Jouzel J, Johnsen S (1998) The cold event 8,200 years ago documented in oxygen isotope record of precipitation in Europe and Greenland. Climate Dynamics 14: 73-81

Grimm E (1992) Tilia 1.11 and Tilia graph 1.17. Springfield: Illinois State Museum, Research and Collection Center

Haas JN (1996) Pollen and plant macrofossil evidence of vegetation change at Wallisellen-Langachermoos (Switzerland) during the Mesolithic-Neolithic transition 8500-6500 years ago. Dissertationes Botanicae 267, J. Cramer, Berlin Stuttgart

Komárek J, Fott B (1983) Chlorophyceae (Grünalgen), Ordnung Chlorococcales. In: Huber-Pestalozzi G (ed) Das Phytoplankton des Süsswassers. Die Binnengewässer 16(7/1), E. Schweizerbart'sche Verlagsbuchhandlung, Stuttgart

Küster H (1997) The role of farming in the postglacial expansion of beech and hornbeam in the oak woodlands of central Europe. The Holocene 7: 239-242

Mangerud J, Andersen ST, Berglund B, Donner JJ (1974) Quaternary stratigraphy of Norden, a proposal for terminology and classification. Boreas 3: 109-128

Marinis R de (1989) Preistoria e protostoria della Valcamonica, Valtrompia e Valsabbia. Aspetti della cultura materiale dal Neolitico all'Età del Ferro. In: Poggiani Keller R (ed) Valtellina e mondo alpino nella preistoria, Modena, pp 101-119

Marziani G, Citterio S (1999) The effects of human impact on the arboreal vegetation near ancient iron smelting sites in Val Gabbia, northern Italy. Vegetation History and Archaeobotany 8: $225-229$

Middeldorp AA (1982) Pollen concentration as a basis for indirect dating and quantifying net organic and fungal production in a peat bog ecosystem. Review of Palaeobotany and Palynology 37: 225-282

Moore PD, Webb JA, Collinson ME (1991) Pollen analysis. Blackwell Scientific Publications, Oxford

Orombelli G (1996) Climatic records in ice cores. Terra Antartica 3: 63-75

Orombelli G, Mason P (1997) Holocene glacier fluctuations in the Italian alpine region. In: Frenzel B, Boulton GS, Gläser B, Huckriede U (eds) Glacier fluctuations during the Holocene. Paläoklimaforschung 24, Special Issue 'European Paleoclimate and Man' 16: 59-65

Orombelli G, Pelfini M (1985) Una fase di avanzata glaciale nell'Olocene Superiore, precedente alla Piccola Glaciazione, nelle Alpi Centrali. Rendiconti della Società Geologica Italiana 8: $17-20$

Orombelli G, Ravazzi C (1995) Le torbe di Cerete Basso (Bergamo): una successione stratigrafica di riferimento per il Tardiglaciale e l'Olocene nelle Prealpi Lombarde. Rendiconti dell'Istituto Lombardo Accademia di Scienze e Lettere, Milano: 185-217.

Patzelt G, Bortenschlager S (1973) Die postglazialen Gletscher- und Klimaschwankungen in der Venedigergruppe (Hohe Tauern, Ostalpen). Zeitschrift für Geomorphologie N. F. 16: 25-72

Pignatti S (1982) Flora d'Italia. Edagricole
Pini R, Mangili C (1998) Modern and sub-fossil pollen deposition in the Pian di Gembro peat-bog (N-Italy). Second Meeting of the European Pollen Monitoring Program, abstracts

Piussi P (1992) Mixed cembran pine stands on the southern slope of the eastern Alps. International Workshop, St. Moritz: 261-268

Punt W, Blackmore S (1976-1995) The Northwest European Pollen Flora. Vol. I-VII, Elsevier Publishing Company

Ravazzi C (2002) Late Quaternary history of spruce (Picea abies Karst.) in southern Europe. Review of Palaeobotany and Palynology 120: 131-177

Reille M (1992-1995) Pollen et spores d'Europe et d'Afrique du Nord. Laboratoire de Botanique historique et Palynologie, Marseille

Schneider R, Tobolski K (1985) Lago di Ganna - Late Glacial and Holocene environments of a lake in the Southern Alps. Dissertationes Botanicae 87: 229-271

Speranza A, Ravazzi C, Baroni C, Carton A, Van Geel B, Mommersteeg H (1996) Holocene vegetation development and human impact in the Central Alps: the 'Pian Venezia' palaeobotanical record (Trento, Italy). Il Quaternario 9: 737-744

Stockmarr J (1971) Tablets with spores used in absolute pollen analysis. Pollen et Spores 13: 615-621

Stuiver M, Reimer PJ, Bard E, Beck WJ, Burr GS, Hughen KA, Kromer B, McCormac G, Plicht J van der, Spurk M (1998) INTCAL98 radiocarbon age calibration, $24,000-0$ cal B.P. Radiocarbon 40: 1041-1083

Tinner W, Ammann B (2001) Timberline paleoecology in the Alps. In: Kull C, Reasoner M, Alverson K (eds) Pages News 9: 9-11

Trautmann W (1953) Zur Unterscheidung fossiler Spaltöffnungen der mitteleuropäischen Coniferen. Flora 140: 523-533

Troels-Smith J (1960) Ivy, mistletoe and elm. Climate indicators Fodder plants. Geological survey of Denmark, IV series 4: 1-32

Welten M (1982) Vegetationsgeschichtliche Untersuchungen in den westlichen Schweizer Alpen; Bern-Wallis. Denkschriften der Schweizerischen Naturforschenden Gesellschaft 95

Wick L (1994) Vegetation development and human impact at the forest limit: palaeoecological studies in the Splügen Pass area, North Italy. In: Biagi P, Nandris J (eds) Highland exploitation in Southern Europe. Monografie di Natura Bresciana 20: 123-132

Wick L (1996) Late glacial and early Holocene palaeoenvironments in Brianza, N-Italy. Il Quaternario 9: 653-660

Wick L, Tinner W (1997) Vegetation changes and timberline fluctuations in the Central Alps as indicators of Holocene climatic oscillations. Arctic and Alpine Research 29: 445-458

Zoller H (1960) Pollenanalytische Untersuchungen zur Vegetationsgeschichte der insubrichen Schweiz. Denkschriften der Schweizerischen Naturforschenden Gesellschaft, Band 83, Abh. 2

Zoller H (1967) Holocene fluctuations of cold climate in the Swiss Alps. Review of Palaeobotany and Palynology 2: 267-269

Zoller H, Athanasiadis N, Heitz-Weniger A (1977) Diagramme Palü 1, Palü 2, Pian di Gembro 1973 and Pian di Gembro 1975. In: Fitze P, Suter J (eds) ALPQUA 5-12.9.1977. Schweizerische Geomorfologische Gesellschaft, Quartärkomm. SNG Zürich, pp 13-16

Zoller H, Erny-Rodmann C, Punchakunnel P (1996) The history of vegetation and land use in the Lower Engadine (Switzerland). Pollen record of the last 13000 years. Nationalpark-Forschung in der Schweiz 86, Zernez

Zoller H, Kleiber H (1971) Vegetationgeschichtliche Untersuchungen in der montanen und subalpinen Stufe der Tessintäler. Verhandlungen der Naturforschenden Gesellschaft in Basel 81: 90-154

Zoller H, Schindler C, Röthlisberger H (1966) Postglaziale Gletscherstände und Klimaschwankungen im Gotthardmassiv und Vorderrheingebiet. Verhandlungen der Naturforschenden Gesellschaft in Basel 77: 97-164 